\title{
Design of a cost-effective electrochlorination system for point-of-use water treatment
}

\author{
Mainak Bhattacharya ${ }^{1,2^{\dagger}}$, Koyel Bandyopadhyay ${ }^{1}$, Anirban Gupta ${ }^{1}$ \\ ${ }^{1}$ Department of Civil Engineering, Indian Institute of Engineering Science and Technology, Shibpur, Howrah, India \\ ${ }^{2}$ Department of Civil Engineering, Indian Institute of Technology, Kanpur, India
}

\begin{abstract}
Bacteriological contamination in drinking water is known to be responsible for the spread of various waterborne diseases. Although chlorine is frequently used as disinfectant in water treatment, low-cost disinfecting technologies in the villages of developing and under-developed countries are not yet successfully implemented. This study contributed in designing a simple and inexpensive water disinfection unit to produce chlorine from the naturally available dissolved chloride of groundwater by electrochlorination, using inert and cheap graphite electrodes. Laboratory-based experiments were performed in both batch and continuous flow reactors to study the effect of time, current, electro charge loading (ECL), and surface area of electrodes in chlorine generation and bacterial inactivation. Controlled experiments in continuous mode in the absence of chlorine further indicated the possibility of partial inactivation of bacteria under the influence of the electric field. Finally, a treatment unit with drilled anodes, and undrilled cathode electrodes, in continuous flow set-up was installed in four schools of four different villages in West Bengal, India. An average residual chlorine concentration and removal efficiency of total coliform in the designed systems were determined as $0.3 \pm 0.07 \mathrm{mg} / \mathrm{L}$, and $98.4 \% \pm 1.6 \%$, respectively.
\end{abstract}

Keywords: Chlorine, Disinfection, Dissolved chloride, Electric field, Electrochlorination

\section{Introduction}

Waterborne diseases are primarily caused due to pathogenic contamination in drinking water, which may even lead to fatal illness [1-3]. The problem arises as a consequence of consuming fecal matter contaminated drinking water, containing pathogenic organisms $[4,5]$. Detection of the indicator organisms - coliforms, in drinking water suggests, simultaneous presence of pathogens [6]. The issue of transmission of waterborne diseases is not limited to underdeveloped countries having comparatively low hygienic standards; there are reports of multiple incidences of waterborne diseases in well-developed countries also [7-11]. Ideally, drinking water should not contain any microorganism known to be pathogenic $[12,13]$. The primary objective of disinfecting drinking water is to inactivate all pathogenic microorganisms, rendering the water microbiologically safe. The practice of disinfection with chlorine is very much common, and widely followed in water treatment plants. Other than chlorination; ultraviolet radiation (UV) [14], ozonation [15], electrochemical methods [16] are the common techniques of disinfection. In places such as Israel, brine solution, available in plenty, is made to flow through an electrolytic cell, and direct current (DC) is passed, leading to electrolysis [17]. This produces sodium hypochlorite $(\mathrm{NaOCl})$ instantaneously, which is a strong disinfectant. $\mathrm{NaOCl}$ is dosed in water in the required concentration to disinfect. The reactions in the aqueous solution in bulk, and in the cathode and anode electrodes can be summarized by the Eq. (1), (2), and (3), (4), respectively [17-19]:

$$
\begin{gathered}
\mathrm{NaCl}+\mathrm{H}_{2} \mathrm{O}+\text { energy } \rightarrow \mathrm{NaOCl}+\mathrm{H}_{2} \\
\text { Cathode reaction: } 2 \mathrm{H}_{2} \mathrm{O}+2 e^{-} \rightarrow \mathrm{H}_{2}(\mathrm{~g})+2 \mathrm{OH}^{-} \\
\text {Anode reactions: } 2 \mathrm{Cl}^{-} \rightarrow \mathrm{Cl}_{2}(\mathrm{~g})+2 e^{-}
\end{gathered}
$$

This is an Open Access article distributed under the terms of the Creative Commons Attribution Non-Commercial License (http://creativecommons.org/licenses/by-nc/3.0/) which permits unrestricted non-commercial use, distribution, and reproduction in any medium, provided the original work is properly cited.

Copyright (c) 2021 Korean Society of Environmental Engineers
Received August 03, 2020 Accepted October 17, 2020

${ }^{\dagger}$ Corresponding author

Email: mbmainak@iitk.ac.in

Tel: +919051906531

ORCID: 0000-0001-6282-8338 


$$
4 \mathrm{OH}^{-} \rightarrow \mathrm{O}_{2}(\mathrm{~g})+2 \mathrm{H}_{2} \mathrm{O}+4 e^{-}
$$

Electrodes of different materials, viz., iridium-oxide [17], platinum [20], platinum-coated titanium [20], ruthenium-coated titanium [20], graphite [20], AISI 430 stainless steel [21] were previously used for electrochlorination. Productive usages of graphite as the electrodes were encouraging, since, the material is inexpensive and inert in nature. Studies investigating various design parameters associated with the system of electrochlorination indicated that longer time of electrolysis (3 h) [20], high concentration of $\mathrm{NaCl}$ in solution [17, 20], and a ratio of 1.33 between anodic to cathodic surface area [20], favored chlorine production. Another study on statistical optimization of production of chlorine from synthetically prepared brine solution concluded that, the passage of $1.8 \mathrm{~A}$ of current for $35 \mathrm{~min}$ in $0.8 \mathrm{M} \mathrm{NaCl}$ solution, might enhance the performance of an electrochlorination system [22]. However, high inter-electrode spacing seemed to negatively impact the efficiency of an electrochlorination system, and an optimum spacing of 0.5 cm was suggested by Khelifa et al. [20]. Validation of the process of electrochlorination as one of the emerging and efficient methods of disinfecting drinking water was previously shown by many researchers [21, 23-25]. In fact, a few researchers also demonstrated that electrochemical remediation of bacterial population is highly effective even for the treatment of wastewater [26-28]. Research related to the current COVID-19 pandemic confirmed the presence of genetic materials of SARS-CoV-2 in wastewater in the Indian subcontinent [29, 30], Australia [31], The Netherlands [32], Germany [33], USA [34], and in many other places. Poor treatment of drinking water, and wastewater, and inadequate sanitation facilities may lead to faecal-oral transmission of SARS-CoV-2 [35]. The practice of electrochemical treatment of aqueous phase might also be effective in order to prevent such transmissions [36].

Although, there are studies on the applications of electrodes made of different materials, the effects of various design parameters, the performance evaluation of experimentally designed electrochlorination systems; a lag still exists in designing a low-cost electrochlorination unit considering relevant physical, electrochemical, and water quality parameters, and validation of the same in simulated, as well as, in real conditions. Furthermore, the usage of $\mathrm{NaOCl}$ in the chlorination systems is associated with uncertainties in ascertaining the quality of $\mathrm{NaOCl}$, as well as, timely supply in rural context. The commercially available elecrochlorination systems employing costly electrodes and prepared brine solution to accurately dose $\mathrm{NaOCl}$ in drinking water, might not be feasible in the rural areas. Therefore, the present research focused in designing a simple, inexpensive electrochlorination system to produce chlorine from the naturally available dissolved chloride in the groundwater using inert, and durable graphite electrodes for point-of-use drinking water treatment in rural areas.

\section{Material and Methods}

\subsection{General Protocol}

Commercially available graphite plates of $5 \mathrm{~mm}$ thickness were cut into rectangles of three different sizes $-80 \mathrm{~mm}$ * $48 \mathrm{~mm}$,
$120 \mathrm{~mm}$ * $48 \mathrm{~mm}$, and $120 \mathrm{~mm}$ * $100 \mathrm{~mm}$, in the workshop of Indian Institute of Engineering Science and Technology (IIEST), Shibpur, and used as electrodes. Borosilicate glass beakers, and polypropylene buckets were used as electrochlorination cell (EC cell) for studies in batch and continuous mode, respectively. Electrodes were placed inside EC cell filled with water, and were connected to a DC power supply. Chlorine generation due to electrochlorination was governed by electro charge loading (ECL) which was expressed as the following Eq. (5),

$$
\text { ECL (Coulombs/L) = }
$$$$
\text { Current (A) * Time (s) / Volume of water (L) }
$$

Analysis of water quality parameters such as $\mathrm{pH}$, conductivity, and total dissolved solids (TDS), were carried out using a portable kit, fitted with different sets of electrodes. The protocols elaborated by American Public Health Association (APHA) [37] were followed to determine hardness (APHA, 2340 C), alkalinity (APHA, 2320 B), chloride (APHA, 4500-Cl ${ }^{-} \mathrm{B}$ ), and total chlorine (APHA, 4500-Cl G), titrimetrically. Bacteriological testing was done by membrane filtration method where, $50 \mathrm{~mL}$ water sample was passed through a sterilized filter paper, and the filter paper was placed on Chromocult Agar (MERCK Limited, Germany), and incubated for $24 \mathrm{~h}$ at $35^{\circ} \mathrm{C}$. The number of red and blue colored colonies formed on the filter paper, representing coliforms and E. coli concentrations in $50 \mathrm{~mL}$ of samples, respectively, were counted manually, and the results were expressed as colony forming units (cfu) per $50 \mathrm{~mL}$ of water samples. However, multiple tube fermentation technique (APHA, Method 9221) [37] was followed for bacteriological testing of the water samples of the electrochlorination systems installed in rural areas, and the results were reported as the most probable number (MPN) per $100 \mathrm{~mL}$ of samples. All the chemicals used for this research were of analytical grade, or better purity.

\subsection{Batch Experiments}

Graphite electrodes were verified towards their effectiveness of chlorine generation from the dissolved chloride of water samples due to passage of DC current in batch set up. An initial experiment was conducted by dissolving chloride ion in the form of $\mathrm{NaCl}$, at chloride concentrations ranging from 50 to $300 \mathrm{mg} \mathrm{L}^{-1}$ in 1 $\mathrm{L}$ de-ionized water. A blank was also prepared without adding any chloride salt in de-ionized water. A constant current of 0.5 A was passed for $30 \mathrm{~s}$ at an ECL of $15 \mathrm{C} / \mathrm{L}$, and total chlorine for each of these chloride concentrations were measured afterwards. Background residual chlorine concentrations were measured before electrochlorination, and this practice was followed for all the subsequent experiments. Two graphite electrodes of dimensions $100 \mathrm{~mm}$ * $120 \mathrm{~mm}$, at $1 \mathrm{~cm}$ inter-electrode spacing, were used for this purpose. Subsequently, four groundwater samples collected from four different locations of West Bengal, India, of varying chemical quality, were tested for chlorine generation using smaller graphite electrodes (120 mm * $48 \mathrm{~mm}$ ). A constant current of $0.5 \mathrm{~A}$ was passed for $1 \mathrm{~min}$, at an inter-electrode spacing of $1 \mathrm{~cm}$, and an ECL of $120 \mathrm{C} / \mathrm{L}$, through $250 \mathrm{~mL}$ water. Aliquots of the water samples were measured for their respective total chlor- 
ine concentrations after electrochlorination.

Groundwater collected from supply at IIEST, Shibpur, was used for further controlled experiments. One such batch experiment was done to find the effect of time of passage of current on the generation of chlorine. Same ECL can be provided by passing lower current for longer time, or by passing higher current for shorter duration. A constant ECL of $120 \mathrm{C} / \mathrm{L}$ was provided in $250 \mathrm{~mL}$ groundwater of IIEST by varying the current, as well as, the time of its passage, to check for any variation in the amount of chlorine generation. In order to check for the changes in total alkalinity and hardness (total and calcium (Ca) hardness) with time at different ECL, another batch experiment was conducted by passing $0.5 \mathrm{~A}$ current for $1 \mathrm{~h}$ through $200 \mathrm{~mL}$ (ECL $0-9,000 \mathrm{C} / \mathrm{L}$ ) of IIEST groundwater using two graphite electrodes ( $80 \mathrm{~mm}$ * $48 \mathrm{~mm}$ ). A conductivity meter was placed inside the reactor to observe any changes in the conductivity, which is indicative of the changes in total dissolved solids of the aqueous solution.

\subsection{Comparison of Batch and Continuous Mode}

Both batch and continuous systems were tested for their relative chlorine generation from the dissolved chloride, naturally present in IIEST groundwater, at identical electrode configuration (electrode dimension $100 \mathrm{~mm}$ * $120 \mathrm{~mm}$, electrode spacing $5 \mathrm{~mm}$, current $4 \mathrm{~A}$ ). Water was allowed to pass through the continuous flow reactor in up-flow mode and the electrodes were carefully placed inside, ensuring no direct contact between the flowing water and electrical connections. The current was fixed at $4 \mathrm{~A}$; but the flow rate was varied, and ECL was calculated as - C/L $=\mathrm{A} * \mathrm{~s} / \mathrm{L}=$ current/flow rate. Water samples were collected from the outlet of the reactor and measured for their respective total chlorine concentrations. Furthermore, a small study related to rise in temperature of the graphite electrodes (electrode dimension $100 \mathrm{~mm}$ * $120 \mathrm{~mm}$, electrode spacing $5 \mathrm{~mm}$ ) due to passage of current (4 A) in both batch (volume $1 \mathrm{~L}$ ), and continuous mode (flow rate $10 \mathrm{~L} / \mathrm{min}$ ) was conducted. Temperature variation was constantly monitored by inserting a thermometer inside the reactor. The flow rate was maintained close to the actual flow rate in field conditions (8 - $10 \mathrm{~L} / \mathrm{min})$.

\subsection{Effect of Surface Area of Electrodes on Chlorine Generation}

Submerged areas of cathode and anode were varied equally to investigate the effect of surface area of electrodes on chlorine generation, at a constant ECL of $30 \mathrm{C} / \mathrm{L}$, in batch mode. Graphite electrodes with $1 \mathrm{~cm}$ inter-electrode spacing were initially submerged in $1 \mathrm{~L}$ of IIEST groundwater. One of the electrodes was not disturbed, and the submerged area of the other one was decreased by pulling with a fairly durable, non-conducting thread, and placing up at an elevated level. A current of $1 \mathrm{~A}$ was passed for $30 \mathrm{~s}$, and samples were collected to measure their respective chlorine concentrations.

Further studies were conducted to find the dependence of chlorine generation on submerged area of electrodes. A few of the electrodes of dimension $100 \mathrm{~mm}$ * $120 \mathrm{~mm}$ were drilled with 64 number of holes of $2 \mathrm{~mm}$ diameter, and electrode surface area was increased because of the drilled holes. Various combinations of undrilled, and drilled graphite electrodes of dimension $100 \mathrm{~mm}$ * $120 \mathrm{~mm}$, at an inter-electrode distance of $4 \mathrm{~mm}$, were used in continuous system by flowing IIEST groundwater at $3.21 \mathrm{~L} / \mathrm{min}$, and passing 3.5 A current at an ECL of $65.4 \mathrm{C} / \mathrm{L}$. For further experiments, graphite plates of dimension $80 \mathrm{~mm}$ * $48 \mathrm{~mm}$ were taken, and the anodes were drilled $\left(\mathrm{Cl}^{-}\right.$to $\mathrm{Cl}_{2}$ reaction occurs in anode) with 40 numbers of holes of $2 \mathrm{~mm}$ diameter. Electrochlorination with drilled anode and undrilled cathode, at 0.5 A current, and 37.5 $\mathrm{C} / \mathrm{L}$ of ECL, were performed in both batch and continuous modes with IIEST groundwater. Sufficient volume of water was sampled from each of these reactors after electrochlorination to analyze for total chlorine concentrations.

\subsection{Disinfection by Electrochlorination}

Moderately contaminated IIEST groundwater (table S1) was passed through an electrochlorination cell (drilled anode, undrilled cathode, electrode dimension $100 \mathrm{~mm}$ * $120 \mathrm{~mm}$, electrode spacing $4 \mathrm{~mm}$, ECL $97.6 \mathrm{C} / \mathrm{L}$, flow rate $2.75 \mathrm{~L} / \mathrm{min}$, current $4.47 \mathrm{~A}$ ) to assess for the improvement in microbiological quality of the treated water. While one sample was collected from the outlet of the reactor immediately after stopping the current, another sampling was done from the reactor after a lag of 3 more minutes since the stoppage of water and current flow. Both the samples were analyzed for their respective total chlorine, total coliform, and E.coli concentrations.

Inactivation of coliforms and E.coli, caused by flowing of water through an electric field, was also investigated. In approximately $10 \mathrm{~L}$ of treated surface water, $1 \mathrm{~mL}$ of untreated surface water of river Hooghly was spiked to add indicator bacteria (coliform). The sample was divided in two portions. To facilitate passage of current, the total dissolved solids (TDS) was increased in one portion by dissolving potassium chloride (KCl) (which will contribute to dissolved $\mathrm{Cl}^{-}$, favoring generation of chlorine), and potassium nitrate $\left(\mathrm{KNO}_{3}\right)$ was dissolved in the other part. These two semi-synthetic water samples were passed through two different electrochlorination cells with identical electrode configurations (drilled anode, undrilled cathode, electrode dimension $48 \mathrm{~mm}$ * $120 \mathrm{~mm}$, current $1 \mathrm{~A}$ ) at a flow of $1.5 \mathrm{~L} / \mathrm{min}$. Samples were collected from the outlet of the two reactors; and total chlorine, total coliform, and E.coli concentrations were measured.

\subsection{Field Trial of Electrochlorination System}

An electrochlorination cell made of $5 \mathrm{~L}$ polypropylene bottle was designed as a continuous flow system with three undrilled graphite cathodes and three drilled (64 holes of $2 \mathrm{~mm}$ diameter) graphite anodes of dimension $100 \mathrm{~mm} * 120 \mathrm{~mm}$, and inter-electrode distances of $4 \mathrm{~mm}$. Field trials of the electrochlorination system were undertaken at the existing water supply arrangements in four high schools of four different villages in the vicinity of Kolkata, India. The reactor was suspended within the water storage tank (Fig. S1). The water entering the storage tank was allowed to pass through the electrochlorination cell, before being stored in the tank. Dissolved chloride and total coliform expressed as the most probable number (MPN) were measured for the untreated water samples. Variation in flow rate and residual chlorine concentrations in the treated water were monitored. Bacteriological testing (MPN) was done for the treated water sam- 
ples to assess the microbiological quality of the water, before and after electrochlorination.

\section{Results and Discussions}

\subsection{Batch Experiments}

Graphite plates were able to withstand the applied DC current, and chlorine was produced successfully through electrochemical oxidation of chloride ions in anode electrode. Chlorine yield varied between 0.2 to $1.5 \mathrm{mg} / \mathrm{L}$ for dosed chloride concentration of 50 to $300 \mathrm{mg} / \mathrm{L}$ in de-ionized water, respectively (Fig. 1(a)). Chlorine generation in varying extent was observed for three groundwater samples collected from various nearby villages of Kolkata, India, and IIEST groundwater (Fig. 1(b)). While elevated levels of dissolved chloride $(\approx 700 \mathrm{mg} / \mathrm{L})$ in IIEST groundwater benefitted in producing more than $1 \mathrm{mg} / \mathrm{L}$ of chlorine, a relatively low concentration of chloride $(20 \mathrm{mg} / \mathrm{L})$ in groundwater of Chandpara village was also able to generate $0.1 \mathrm{mg} / \mathrm{L}$ of chlorine in $1 \mathrm{~min}$ at an ECL of $120 \mathrm{C} / \mathrm{L}$. Comparable chloride concentrations of Mandalhat (42 $\pm 2 \mathrm{mg} / \mathrm{L}$ ), and Chuadanga (52 $\pm 7 \mathrm{mg} / \mathrm{L})$ villages resulted in similar chlorine production $(0.4-0.5 \mathrm{mg} / \mathrm{L})$ in these two groundwater samples. No residual chlorine was detected in any of these water samples before electrochlorination. When current was varied along with the time of its passage for a fixed ECL of $120 \mathrm{C} / \mathrm{L}$ in IIEST groundwater, lower applied current for longer duration resulted in generation of higher concentration of chlorine (Fig. 1(c)). Rapid generation of chlorine due to higher current within shorter time probably did not allow adequate dissolution of the generated chlorine in the aqueous solution.

Gradual decrease in alkalinity (Fig. 2(a)), and hardness (total and Ca-hardness) (Fig. 2(b)) with time was observed in IIEST groundwater for an applied current of 0.5 A for $60 \mathrm{~min}$. Nearly $40 \%$ decrease in alkalinity, and 30\% decrease in total hardness were observed after $60 \mathrm{~min}$; however, most of the reduction occurred within 30 min. Removal of calcium hardness was more pronounced compared to removal of magnesium hardness (Mg-hardness = Total hardness - Ca hardness) (Fig. 2(b)). Decrease in alkalinity and calcium hardness indicated the possibility of precipitation of both dissolved calcium, and carbonate, most likely as calcite $\left(\mathrm{CaCO}_{3}\right)$, during electrochlorination. Chemistry and the mechanisms involved in this whole process can be a probable scope for further research.

\subsection{Comparison of Batch and Continuous Mode}

Increased ECL favored chlorine generation in both batch and continuous modes of operation (Fig. 3(a)). Higher chlorine concentration was detected in the continuous system, as compared to the batch system, at similar ECL (Fig. 3(a)). Continuous sweeping
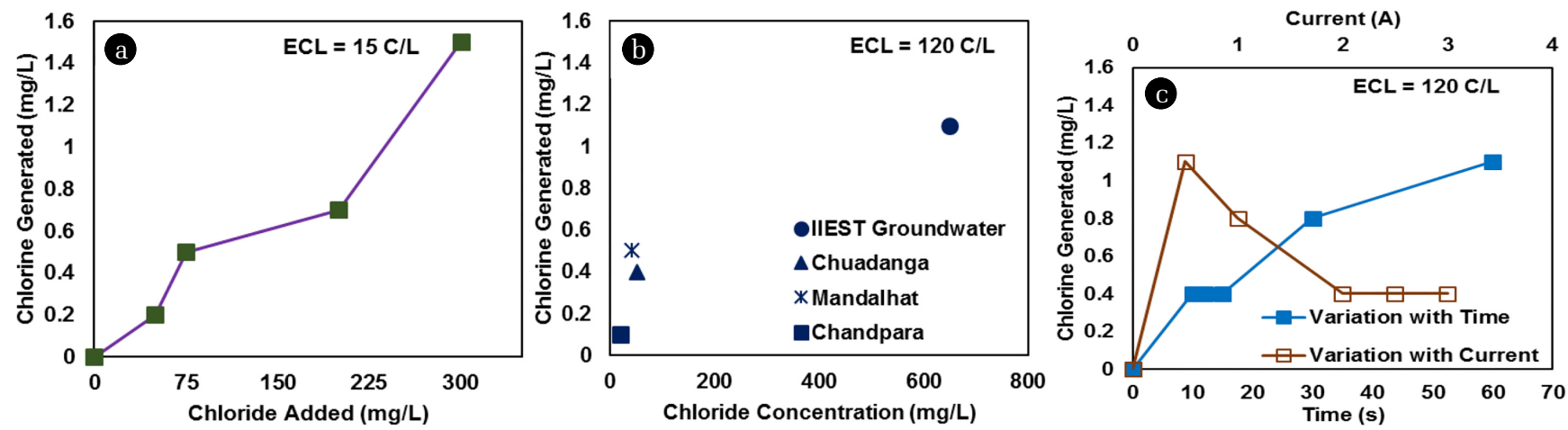

Fig. 1. Variation of chlorine generation due to electrochlorination in batch reactors (a) in de-ionized water with dissolved $\mathrm{NaCl}$ at various concentrations in $30 \mathrm{~s}$, (b) in groundwater collected from four different locations with dissimilar dissolved chloride concentrations in 1 min, (c) with time, and current in IIEST groundwater at $120 \mathrm{C} / \mathrm{L} \mathrm{ECL}$.
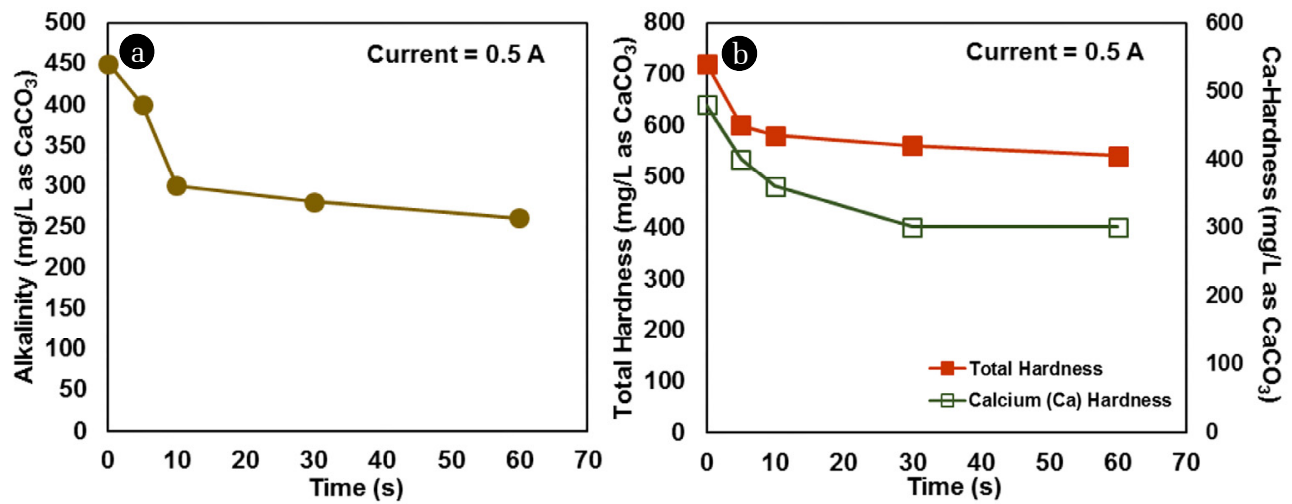

Fig. 2. Changes in (a) alkalinity, (b) total hardness and calcium hardness, with time of passage of current in IIEST groundwater. 

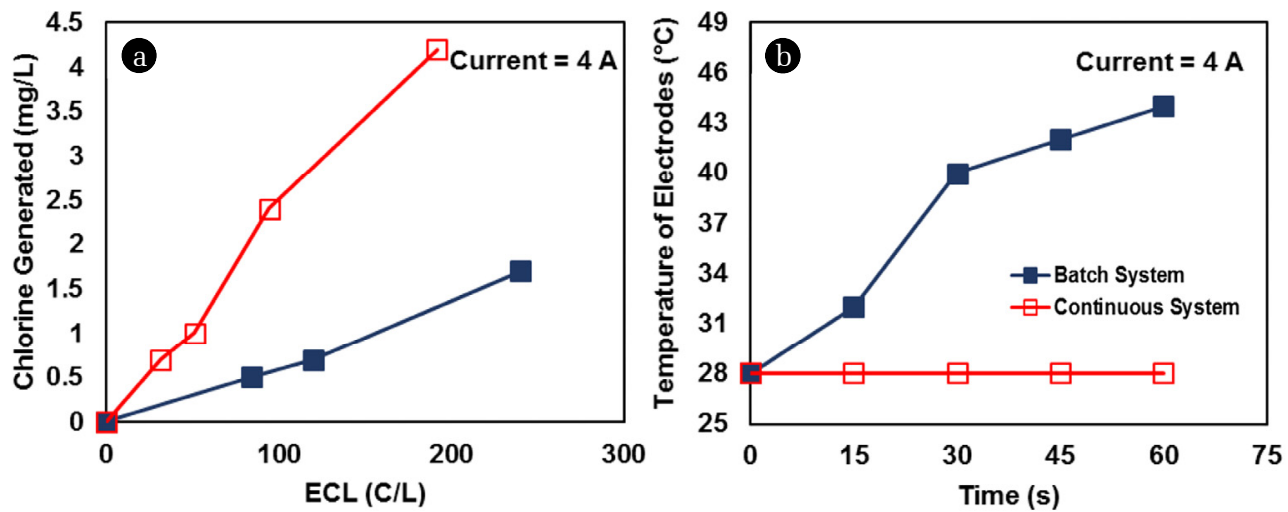

Fig. 3. Variation of (a) chlorine generation with $\mathrm{ECL}$, and (b) temperature of graphite electrodes with time, in batch, and continuous system due to passage of $4 \mathrm{~A}$ current in IIEST groundwater.

of chlorine near the electrode surfaces by the flowing water was the major reason for such high chlorine concentrations. The follow up study indicated the temperature rise of the graphite electrodes by more than $10-12^{\circ} \mathrm{C}$ in batch mode within $1 \mathrm{~h}$ (Fig. 3(b)), strengthening the possibilities of wearing out of the graphite plates. No substantial increase of temperature of the graphite electrodes within this $1 \mathrm{~h}$ time scale was observed in case of the continuous mode of operation (Fig. 3(b)), providing a scope for prolonged usage of the graphite plates as electrodes in continuous flow reactors.

\subsection{Effect of Surface Area of Electrodes on Chlorine Generation}

The decrease in the submerged surface area of anode electrode by $37.5 \%$ greatly reduced chlorine generation from 0.8 to $0.5 \mathrm{mg} / \mathrm{L}$ in IIEST groundwater. However, the decrease of submerged surface area of cathode electrode by the same amount (37.5\%) caused a small drift in chlorine generation from 0.8 to $0.7 \mathrm{mg} / \mathrm{L}$ (Table 1). Thus, chlorine production was noted to be more sensitive towards changes in the submerged area of anode than that of cathode. Electrochlorination, involving oxidation of chloride $\left(\mathrm{Cl}^{-}\right)$to chlorine $\left(\mathrm{Cl}_{2}\right)$ in anode, seemed to be a surface sensitive process.

Controlled experiments with drilled graphite electrodes in the continuous flow reactor elucidated that chlorine generation rapidly increased when the anode was drilled, but did not improve when undrilled cathode and anode, or drilled cathode and undrilled anode electrodes were used (Fig. 4(a)). For drilled electrodes, the additional area within the peripheral surface of the drill was gained, and the area at the surface of the electrode was lost for each circular drill. But the available net area of $5 \mathrm{~mm}$, and $10 \mathrm{~mm}$ thick (t) electrodes increased after drilling $2 \mathrm{~mm}$ diameter (D) holes $\left(\pi \mathrm{Dt}>\pi \mathrm{D}^{2} / 4\right)$. Moreover, drilling would also help in migration of ions to facilitate utilization of both the surfaces of the electrodes. This result also indicated that chlorine generation was more sensitive towards the submerged surface area of anode and validated the earlier observations of Table 1 . When both anodes and cathodes were drilled with equal number of holes of equal diameters, chlorine generation marginally increased. The increase in chlorine production was even lower with undrilled anode and drilled cathode electrodes (Fig. 4(a)). Highest chlorine production with the drilled anode and undrilled cathode electrodes signified the importance of not only keeping a higher surface area of electrodes, but also a ratio of submerged surface area of anodes to that of cathodes more than 1 , as suggested previously by Khelifa et al. [20]. Further experiments with drilled anodes and undrilled cathode electrodes confirmed that, drilled anodes helped for generation of increased chlorine in both batch and continuous mode of operation, and more chlorine was generated for continuous flow reactor as compared to the batch reactor (Fig. 4(b)), which was consistent with the earlier results.

\subsection{Disinfection by Electrochlorination}

Electrochlorination was aimed to render water samples safe from pathogenic contamination, through adequate disinfection. The initial experiment, with undrilled cathode and drilled anode electrodes in IIEST groundwater at a continuous flow of $2.75 \mathrm{~L} / \mathrm{min}$

Table 1. Chlorine Generation in IIEST Groundwater for Varying Submerged Surface Area of Electrodes at $30 \mathrm{C} / \mathrm{L}$ ECL in Batch Reactors

\begin{tabular}{|c|c|c|c|c|}
\hline $\begin{array}{l}\text { Submerged surface area of anode } \\
\left(\mathrm{mm}^{*} \mathrm{~mm}\right)\end{array}$ & $\begin{array}{l}\text { Submerged surface area of cathode } \\
\left(\mathrm{mm}^{*} \mathrm{~mm}\right)\end{array}$ & $\begin{array}{l}\text { Current } \\
\text { (A) }\end{array}$ & $\begin{array}{c}\text { Time } \\
\text { (s) }\end{array}$ & $\begin{array}{c}\text { Chlorine generated } \\
(\mathrm{mg} / \mathrm{L})\end{array}$ \\
\hline \multicolumn{5}{|c|}{ Fully submerged anode and cathode } \\
\hline $80 * 48$ & $80 * 48$ & 1 & 30 & 0.8 \\
\hline \multicolumn{5}{|c|}{ Decrease in submerged area of anode } \\
\hline $50 * 48$ & $80 * 48$ & 1 & 30 & 0.5 \\
\hline \multicolumn{5}{|c|}{ Decrease in submerged area of cathode } \\
\hline $80 * 48$ & $50 * 48$ & 1 & 30 & 0.7 \\
\hline
\end{tabular}



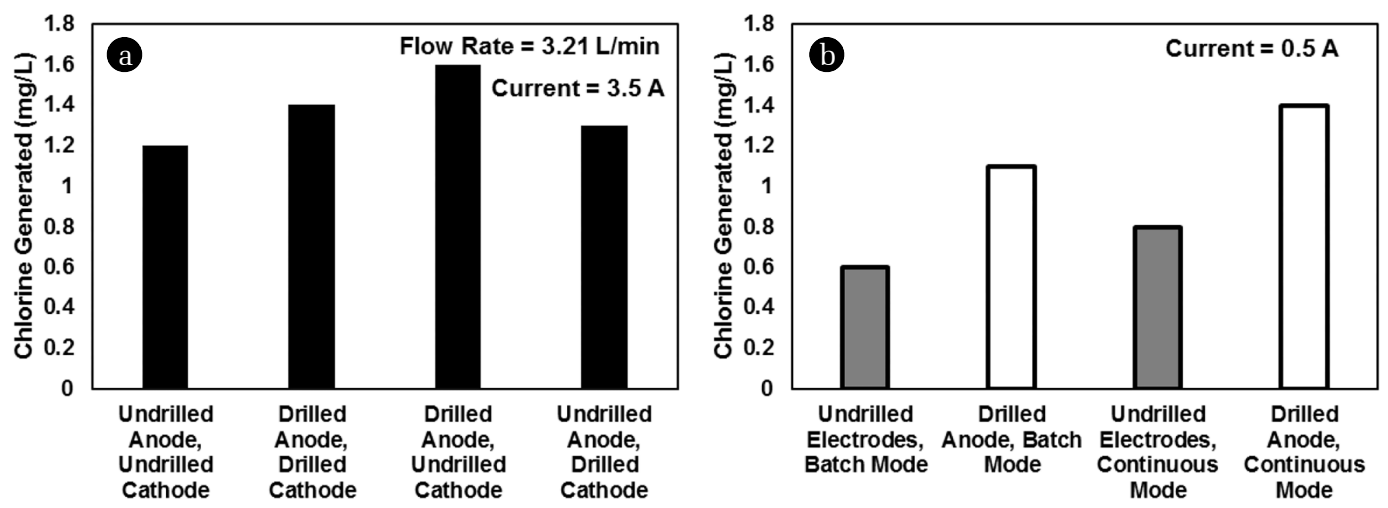

Fig. 4. Chlorine generation (a) with combinations of undrilled, and drilled electrodes in continuous system, (b) with undrilled, and drilled anode electrodes in batch and continuous mode, in IIEST groundwater.

ensured an immediate decrease in the total coliforms and E.coli count of the water from 38 to $3 \mathrm{cfu} / 50 \mathrm{~mL}$, and 2 to $0 \mathrm{cfu} / 50$ $\mathrm{mL}$, respectively (Fig. 5(a)). The concentration of total coliforms decreased to 0 after $3 \mathrm{~min}$ detention of the flowing water (Fig. 5(a)). Residual chlorine concentration after electrochlorination was $2.6 \mathrm{mg} / \mathrm{L}$, and remained the same after 3 min detention.

The observed bacterial inactivation in electrochlorination system was principally caused by the generated chlorine. The semi-synthetic water, prepared for a controlled experiment in the continuous mode to check for bacterial remediation of water by the passage of DC current, was measured to have $250 \mathrm{mg} / \mathrm{L}$ of TDS. Concentrations of the increased TDS in the $\mathrm{KCl}$, and $\mathrm{KNO}_{3}$ containing reactors were measured to be $1,442 \mathrm{mg} / \mathrm{L}$, and 1,778 $\mathrm{mg} / \mathrm{L}$, respectively. Total coliform concentration of $80 \mathrm{cfu} / 50 \mathrm{~mL}$, and E.Coli concentration of $7 \mathrm{cfu} / 50 \mathrm{~mL}$ was determined in this semi-synthetic sample. Passage of 1 A current with drilled anode, and undrilled cathode electrodes in the water flowing at $1.5 \mathrm{~L} / \mathrm{min}$ generated $0.9 \mathrm{mg} / \mathrm{L}$ of chlorine in the water where $\mathrm{KCl}$ was added, and no chlorine was traced in the $\mathrm{KNO}_{3}$-added water (Fig. 5(b)). The bacteriological results indicated removal of $90 \%$ of total coli- forms, and 100\% of E.coli (Fig. 5(b)) when chlorine was generated (water with $\mathrm{KCl}$ ); and total coliforms, and E.coli concentrations also showed their respective removal to an extent of $80 \%$, and 85.7\% even when no chlorine was generated (Fig. 5(b)). Thus, the electric field imposed on the bacteria during its passage through the electrochlorination cell was also responsible for bacterial inactivation. A previous study [22] also suggested the possibility of remediation of bacteriological contamination under the influence of the electric field. It can be broadly stated that electrochlorination caused inactivation of pathogens (coliforms) by a combination of electric field and generated chlorine. The importance of this result from practical application point of view is high as the electrochlorination system can be effective for installations even in locations with relatively low level of chloride concentrations in the water to be disinfected. Flow rate can be controlled to expose the water samples in the electric field for longer duration to improve the efficiency of disinfection.

\subsection{Field Trials of Electrochlorination System}

The designed electrochlorination system in continuous mode with
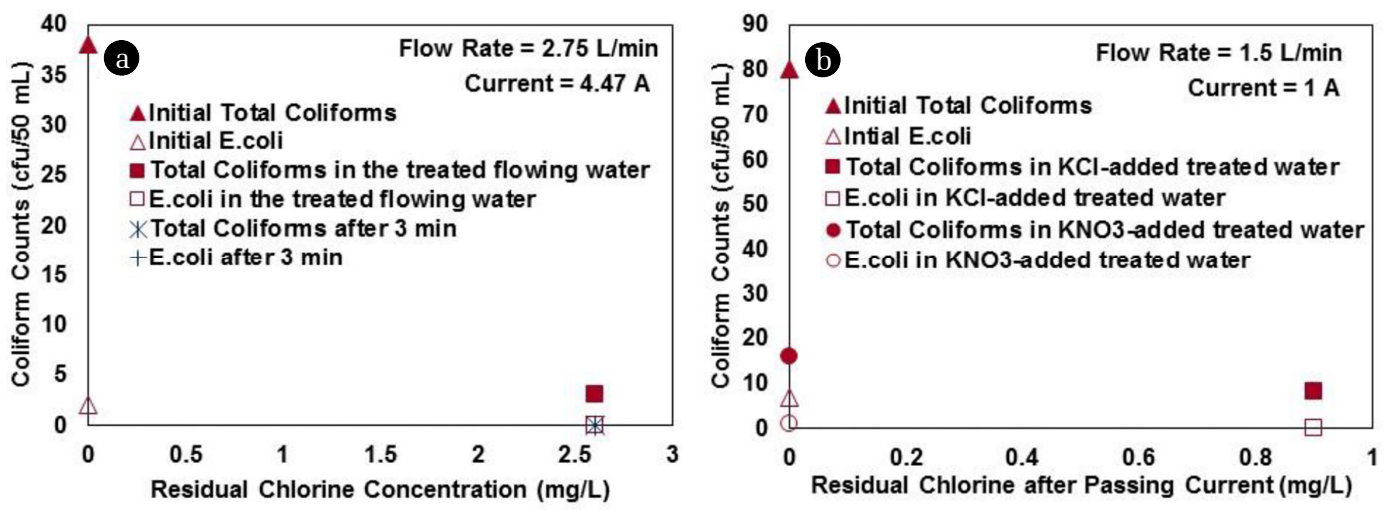

Fig. 5. (a) $)^{\#}$ Removal of coliforms by electrochlorination from IIEST groundwater using undrilled cathode and drilled anode electrode in continuous mode at an ECL of $97.6 \mathrm{C} / \mathrm{L}$, (b) Inactivation of coliforms in semi-synthetic water by passing $1 \mathrm{~A}$ current using undrilled cathode and drilled anode electrode in the presence and absence of dissolved chloride ion in continuous mode at $40 \mathrm{C} / \mathrm{L} \mathrm{ECL}$.

${ }^{\#}$ E.coli concentration was zero immediately after electrochlorination. Total coliforms, and E.coli concentrations were zero after 3 minutes of detention time in the reactor. 
Table 2. Inactivation of Coliforms in the Electrochlorination Systems Installed in Schools of Rural Areas of West Bengal, India

\begin{tabular}{|c|c|c|c|c|c|c|c|}
\hline Location ${ }^{\#}$ & $\begin{array}{c}\text { Flow rate } \\
(\mathrm{L} / \mathrm{min})^{\$}\end{array}$ & $\begin{array}{l}\text { Current } \\
\text { (A) }\end{array}$ & $\begin{array}{l}\text { ECL } \\
(C / L)^{\$}\end{array}$ & $\begin{array}{c}\text { Chloride } \\
\text { content } \\
(\mathrm{mg} / \mathrm{L})\end{array}$ & $\begin{array}{c}\text { Chlorine } \\
\text { produced } \\
(\mathrm{mg} / \mathrm{L})^{\$}\end{array}$ & $\begin{array}{l}\text { Coliforms in raw } \\
\text { water } \\
\text { (MPN/100 mL) }\end{array}$ & $\begin{array}{l}\text { Coliforms in } \\
\text { treated water } \\
(\mathrm{MPN} / \mathbf{1 0 0} \mathbf{~ m L})\end{array}$ \\
\hline $\begin{array}{l}\text { Shikarpur High School, } \\
\text { Chakdah, Nadia }\end{array}$ & $8-10$ & 13 & $78-98$ & 135 & $0.3-0.4$ & 80 & 2 \\
\hline $\begin{array}{l}\text { Bora High School, Gaighata, } \\
\text { N24 Parganas }\end{array}$ & $8-10$ & 13 & $78-98$ & 65 & $0.2-0.3$ & 220 & 8 \\
\hline $\begin{array}{l}\text { Kalasima Swami Vivekananda High } \\
\text { School, Habra, N24 Parganas }\end{array}$ & $8-10$ & 20 & $120-150$ & 40 & $0.2-0.3$ & 100 & 0 \\
\hline $\begin{array}{l}\text { Sabaipur High School, Gaighata, } \\
\text { North } 24 \text { Parganas. }\end{array}$ & $8-10$ & 11 & $66-82.5$ & 20 & 0.2 & 8 & 0 \\
\hline
\end{tabular}

\footnotetext{
\# Name of the school, followed by the name of the village, and district were mentioned while describing the locations.

$\$$ These parameters were varying naturally at the field conditions. Respective minimum, and maximum values were mentioned as the range of variation for these parameters.
}

drilled anodes, and undrilled cathodes were finally installed in four villages near Kolkata, India, for remediation of pathogens from drinking water. Electrode, as well as, reactor configurations were chosen based on the results of all the controlled experiments, illustrated previously. The results, presented in table 2, indicated variation of a few parameters viz., flow rate, ECL, and chlorine generation at the site. All the treatment units were effective in $97 \%-100 \%$ reduction in coliform counts in the samples collected from the outlet of the electrochlorination cell, with residual chlorine concentrations varying between 0.2 to $0.4 \mathrm{mg} / \mathrm{L}$ (Table 2). Additional detention time available within the storage tanks might enhance the efficiency of these disinfection units.

However, deposition of coating on the surfaces of cathodes was observed during prolonged use, which led to rise in voltage and drop in current. The problem encountered in the electrochlorination system was similar to passivation in electrochemical cells. The solid deposit was scrapped from the surfaces of the cathode electrodes, dissolved in concentrated $\mathrm{HCl}$, and was found to be rich in calcium. Cathode electrodes with white coating from the field were set as anodes, and current was passed in $1 \mathrm{~L}$ of IIEST groundwater. This electrode reversal resulted in gradual dissolution of the coating (from anode), and the electrodes were visibly becoming free of deposition. Increase of current with time as the deposits dissolved, was observed (Table 3). However, dissolution of the white coating of calcium increased the hardness of water (Table 3). The decrease in both alkalinity and calcium-hardness due to electrochlorination (Fig. 2) can be explained from the possibility

Table 3. Changes in Current and Total Hardness in IIEST Groundwater after Electrode Reversal\#

\begin{tabular}{lcc}
\hline $\begin{array}{l}\text { Time } \\
(\mathbf{m i n})\end{array}$ & $\begin{array}{c}\text { Current } \\
\text { (A) }\end{array}$ & $\begin{array}{c}\text { Total Hardness in water } \\
\left(\mathbf{m g} / \mathrm{L} \text { as } \mathrm{CaCO}_{3}\right)\end{array}$ \\
\hline 0 & 0 & 840 \\
5 & 3.79 & 940 \\
180 & 4.79 & 15,000 \\
\hline
\end{tabular}

\# Electrodes from sites were brought to the laboratory, and cathode electrodes with deposits were used as anodes and vice-versa. of precipitation of calcium carbonate. Electrode reversal was helpful for release of calcium from calcium carbonate coatings on cathode once the electrical poles of the electrodes were reversed. Therefore, for practical applications, periodic reversal of electrodes will help in dissolution of the deposits from the electrodes, allowing prolonged use of the electrochlorination cells without encountering the problem of passivation. Frequency of electrode reversal will depend on the respective water quality, especially alkalinity and hardness of the water.

\subsection{Cost Analysis}

A cost analysis of the designed electrochlorination system was conducted to plan its usage for robust field applications. For a design period of 5 years, maximum gross monthly cost, and maximum per L cost of electrochlorination were estimated to be INR 3,908 (US\$ 54.27778), and INR 0.033 (US\$ 0.00046), respectively (table S2). Moreover, for a total of 1,000 number of beneficiaries in the rural school, a per capita monthly cost of INR 3.908 (US\$ 0.05428) was calculated. Previously, a study estimated per L cost of NaOCl-based electrochlorination system as INR 0.1692 (US\$ 0.00235) [38]. Another research suggested that a per capita monthly cost of INR 5.6 (US\$ 0.07778) approximately would be required to operate a $\mathrm{NaOCl}$-based electrochlorination system in the rural areas [39]. Usage of $\mathrm{NaOCl}$ or brine solution enhanced the cost of these electrchlorination systems, as compared to the electrochlorination system designed in the present study. The cost of our elecrtochlorination system is very much affordable, and can be of good help in the rural areas of the developing countries.

\section{Conclusions}

Passage of current through water using graphite electrodes was able to produce chlorine by electrochemical oxidation of the dissolved chloride ion, naturally present in the samples. Higher chlorine generation, and stability in the temperature of graphite electrodes were detected in the continuous flow systems, as compared to the batch reactors. Chlorine production was more sensitive 
towards anodic surface area, and drilling of anodes further increased the chlorine generation. Inactivation of total coliforms and E. coli was observed in moderately contaminated IIEST groundwater. It was also established that, inactivation of coliforms can be caused by the applied electric field during electrochlorination, in addition to the effects of generated chlorine. The designed electrochlorination system was installed in four villages of West Bengal, India, with three undrilled cathodes and three drilled anodes in each electrochlorination cell, at a range of flow rate of $8-10 \mathrm{~L} / \mathrm{min}$. A minimum of $97 \%$, and maximum of $100 \%$ inactivation efficiency for total coliforms were detected in these field set-ups. Decrease in both alkalinity and hardness, and appearance of white solid depositions on the cathode electrodes during prolonged usage, were indicative of precipitation of calcium carbonate. Passivation problem due to deposition on the cathode electrodes was overcome by reversing the poles of the electrodes, as the deposits dissolved out. Increase in hardness after electrode reversal suggested dissolution of calcium from the solid phase. Maximum per L cost of the treated water from this designed electrochlorination system was INR 0.033 (US\$ 0.00046). The capital cost for one such installation for a design period of 5 years was estimated to be INR 17,000 (US\$ 223). The designed electrochlorination system was suitable to apply in schools and communities in rural areas of the developing countries, to supply drinking water safe from microbiological contamination.

\section{Acknowledgment}

The authors are grateful to a Kolkata-based NGO, "SATHEE", for helping during the field works. This research did not receive any specific grant from any funding agencies in the public, commercial, or not-for-profit sectors. However, the authors are thankful to Ministry of Human Resources and Development (MHRD) for providing the facilities in the laboratory of Indian Institute of Engineering Science, and Technology (IIEST), Shibpur, and for providing GATE scholarships to the graduate students.

\section{Author Contributions}

M.B. (Ph.D. student) conducted the majority of the experiments, and wrote the manuscript. K.B. (M.Tech student) performed two experiments. A.G. (Professor) revised the manuscript.

\section{References}

1. Macler BA, Merkle JC. Current knowledge on groundwater microbial pathogens and their control. Hydrog. J. 2000;8(1): 29-40.

2. Gibson KE. Viral pathogens in water: occurrence, public health impact, and available control strategies. Curr. Opin. Virol. 2014;4:50-57.

3. Gerba C. P. 1983. Pathogens. In: Page AL, Gleason TL, Smith JE, Iskander IK, Sommers LE, eds. Utilization of Municipal Wastewater and Sludge on Land; 1983; University of California,
Riverside, CA (1983). p. 147-187.

4. Forstinus NO, Ikechukwu NE, Emenike MP, Christiana AO. Water and waterborne diseases: A review. Int. J. Trop. Dis. 2016;12(4):1-4.

5. Sokolova E, Åström J, Pettersson TJ, Bergstedt O, Hermansson M. Estimation of pathogen concentrations in a drinking water source using hydrodynamic modelling and microbial source tracking. J. Water Health. 2012;10(3):358-370.

6. Gerba CP. Indicator microorganisms. Environmental microbiology. Academic Press; 2009. p. 485-499.

7. Schoenen D. Role of disinfection in suppressing the spread of pathogens with drinking water: possibilities and limitations. Water Res. 2002;36(15):3874-3888.

8. Taylor A, Craun GF, Faich GA, McCabe LJ, Gangarosa EJ. Outbreaks of waterborne diseases in the United States, 1961-1970. J. Infect. Dis. 1972;125(3):329-331.

9. Moore AC, Herwaldt BL, Craun GF, Calderon RL, Highsmith AK, Juranek DD. Waterborne disease in the United States, 1991 and 1992. J. Am. WATER Work. Assoc. 1994;86(2):87-97.

10. Kramer MH, Quade G, Hartemann P, Exner M. Waterborne diseases in Europe-1986-96. J. Am. WATER Work. Assoc. 2001;93(1):48-53.

11. Kim S. Salmonella serovars from foodborne and waterborne diseases in Korea, 1998-2007: total isolates decreasing versus rare serovars emerging. J. Korean Med. Sci. 2010;25(12): 1693-1699.

12. World Health Organization. Guidelines for drinking water quality. $3^{\text {rd }}$ ed. Geneva: WHO Press; 2008. p. 283.

13. Bureau of Indian Standards. IS 10500 drinking water specification. $2^{\text {nd }}$ rev. New Delhi: BIS; 2012. p. 4.

14. Song K, Mohseni M, Taghipour F. Application of ultraviolet light-emitting diodes (UV-LEDs) for water disinfection: A review. Water Res. 2016;94:341-349.

15. Von Gunten U. Ozonation of drinking water: Part II. Disinfection and by-product formation in presence of bromide, iodide or chlorine. Water Res. 2003;37(7):1469-1487.

16. Li H, Zhu X, Ni J. Comparison of electrochemical method with ozonation, chlorination and monochloramination in drinking water disinfection. Electrochim. Acta. 2011;56(27): 9789-9796.

17. Choi J, Shim S, Yoon J. Design and operating parameters affecting an electrochlorination system. J. Ind. Eng. Chem. 2013; 19(1):215-219.

18. Czarnetzki LR, Janssen LJ. Formation of hypochlorite, chlorate and oxygen during $\mathrm{NaCl}$ electrolysis from alkaline solutions at an RuO 2/TiO 2 anode. J. Appl. Electrochem. 1992;22(4): 315-324.

19. Szpyrkowicz L, Naumczykt J, Zilio-Grandi F. Application of electrochemical processes for tannery wastewater treatment. Toxicol. Environ. Chem. 1994;44(3-4):189-202.

20. Khelifa A, Moulay S, Hannane F, Benslimene S, Hecini M. Application of an experimental design method to study the performance of electrochlorination cells. Desalination 2004; 160(1):91-98.

21. Abderrahmane S, Himour A, Ponsonnet L. Inactivation of E. coli and Pseudomonas aeruginosa by electrochloration under bipolar pulsed polarization. Mater. Sci. Eng. C. 2008;28(5-6): 
901-905.

22. Zaviska F, Drogui P, Pablo G. Statistical optimization of active chlorine production from a synthetic saline effluent by electrolysis. Desalination 2012;296:16-23.

23. Jeong J, Kim JY, Cho M, Choi W, Yoon J. Inactivation of Escherichia coli in the electrochemical disinfection process using a Pt anode. Chemosphere 2007;67(4):652-659.

24. Martínez-Huitle CA, Brillas E. Electrochemical alternatives for drinking water disinfection. Angew. Chem. Int. Ed. 2008;47(11): 1998-2005.

25. Saha J, Gupta SK. A novel electro-chlorinator using low cost graphite electrode for drinking water disinfection. Ionics 2017;23(7):1903-1913.

26. Diao HF, Li XY, Gu JD, Shi HC, Xie ZM. Electron microscopic investigation of the bactericidal action of electrochemical disinfection in comparison with chlorination, ozonation and Fenton reaction. Process Biochem. 2004;39(11):1421-1426.

27. Birbir Y, Uğur G, Birbir M. Inactivation of bacterial population in hide-soak liquors via direct electric current. J. Electrostat. 2008;66(7-8):355-360.

28. Gotsi M, Kalogerakis N, Psillakis E, Samaras P, Mantzavinos D. Electrochemical oxidation of olive oil mill wastewaters. Water Res. 2005;39(17):4177-4187.

29. Kumar M, Patel AK, Shah AV, Raval J, Rajpara N, Joshi M, Joshi CG. First proof of the capability of wastewater surveillance for COVID-19 in India through detection of genetic material of SARS-CoV-2. Sci. Total Environ. 2020;746:141326.

30. Bhowmick GD, Dhar D, Nath D, Ghangrekar MM, Banerjee R, Das S, Chatterjee J. Coronavirus disease 2019 (COVID-19) outbreak: some serious consequences with urban and rural water cycle. NPJ Clean Water. 2020;3(1):1-8.

31. Ahmed W, Angel N, Edson J, Bibby K, Bivins A, O'Brien JW, Choi PM, Kitajima M, Simpson SL, Li J, Tscharke B. First confirmed detection of SARS-CoV-2 in untreated wastewater in Australia: A proof of concept for the wastewater surveillance of COVID-19 in the community. Sci. Total Environ. 2020;728: 138764.

32. Lodder W, de Roda Husman AM. SARS-CoV-2 in wastewater: potential health risk, but also data source. Lancet Gastroenterol. Hepatol. 2020;5(6):533-534.

33. Westhaus S, Weber FA, Schiwy S, Linnemann V, Brinkmann M, Widera M, Greve C, Janke A, Hollert H, Wintgens T, Ciesek S. Detection of SARS-CoV-2 in raw and treated wastewater in Germany-Suitability for COVID-19 surveillance and potential transmission risks. Sci. Total Environ. 2020;751:141750.

34. Hart OE, Halden RU. Computational analysis of SARS-CoV-2/COVID-19 surveillance by wastewater-based epidemiology locally and globally: Feasibility, economy, opportunities and challenges. Sci. Total Environ. 2020;730:138875.

35. Gwenzi W. Leaving no stone unturned in light of the COVID-19 faecal-oral hypothesis? A water, sanitation and hygiene (WASH) perspective targeting low-income countries. Sci. Total Environ. 2020;753:141751.

36. Bhatt A, Arora P, Prajapati SK. Occurrence, fates and potential treatment approaches for removal of viruses from wastewater: A review with emphasis on SARS-CoV-2. J. Environ. Chem. Eng. 2020;8(5):104429.

37. American Public Health Association, American Water Works Association, Water Environment Federation. Standard methods for the examination of water and waste water. $20^{\text {th }}$ ed. 1999.

38. Badruzzaman M, Oppenheimer J, Adham S, Kumar M. Innovative beneficial reuse of reverse osmosis concentrate using bipolar membrane electrodialysis and electrochlorination processes. J. Membr. Sci. 2009;326(2):392-399.

39. Key JD. Development of a small-scale electro-chlorination system for rural water supplies [dissertation]. Cape Town: University of the Western Cape; 2010. 